\title{
Diversity and ecology of Pilargidae (Annelida: Polychaeta) from the Gulf of Carpentaria and Arafura Sea, northern Australia
}

\author{
SHONA A. HOCKNULL ${ }^{1,3}$ \& CHRISTOPHER J. GLASBY ${ }^{2}$ \\ ${ }^{\prime}$ Benthic Australia Pty Ltd, PO Box 5354, Manly, Queensland 4154, Australia. E-mail:shona.hocknull@ benthicaustralia.com \\ ${ }^{2}$ Museum and Art Gallery of the Northern Territory, GPO Box 4646, Darwin, NT 0801, Australia. E-mail: chris.glasby@nt.gov.au \\ ${ }^{3}$ Corresponding author
}

\begin{abstract}
This study identifies to species or species units 572 lots (>1000 specimens) of pilargids from six localities in the Arafura Sea and Gulf of Carpentaria (including the ports at Gove and McArthur River). We analyze the taxonomic data against geomorphic unit, depth, and sediment type. Preliminary results show that pilargid fauna of northern Australia comprises 13 species in seven genera (Ancistrosyllis, Cabira, Litocorsa, Loandalia, Pilargis, Sigambra, and Synelmis). Although all four localities have a similar diversity of species (six or seven species each), the species composition differs between each region: Litocorsa annamita and Synelmis rigida were found in all sediment types in the Arafura Sea and Gulf of Carpentaria; Ancistrosyllis cf. hartmanae (mud and sand dominated sediments only) and Sigambra pettiboneae (all sediment types) were restricted to the inshore localities of Gove and McArthur River; Loandalia gladstonensis and Sigambra sp. 2 were found on the shelf and in the inshore habitats of the Gulf of Carpentaria only; Litocorsa sp. 'arafura', Sigambra sp. 'arafura' and Synelmis gibbsi were found only in the Arafura Sea, with sediments dominated by sand and gravel; and Cabira sp. 1 and Sigambra cf. tentaculata were found at all locations, in all sediment types. Based on these distribution patterns and the Recent Quaternary geological history of the area, hypotheses of post-glacial colonization of the Gulf of Carpentaria are presented. The pilargid species composition in northern Australia is also compared to neighboring Indo-west Pacific regions.
\end{abstract}

Key words: Indo-west Pacific, Arafura Sea, Gove, McArthur River, systematics, ecology, habitat, biogeography, diversity

\section{Introduction}

Pilargids are free-living sediment dwellers, found throughout the oceans from abyssal plains to inshore shelf waters, estuaries, and lagoons (Glasby 2000). Members of the group are normally thought of as being rare (e.g., Salazar-Vallejo 1987; Salazar-Vallejo \& Orensanz 1991; Fiege \& Böggemann 1999), but other studies (e.g., Flint \& Rabalais 1980; Nishi et al. 2007) and the present data suggest that members of some genera, particularly Litocorsa or Sigambra, may be well represented in shelf sediments. In the Australasian region there is a lack of published records on the group, even though pilargids are regularly collected in benthic samples. Consequently little is known about habitat preferences and biogeography of Australian pilargids. Moreover, studies on polychaetes of the northeastern Australian shelf are limited to a few reports and ecology papers including Long \& Poiner (1994), Wilson (2006) and Russell \& Smit (2007). Other studies of benthic invertebrates in the Gulf of Carpentaria have only considered the larger epibenthic forms. 
In northern Australia, the Gulf of Carpentaria (GoC) and Arafura Sea are adjacent water bodies separated by the shallow (55 m) Arafura Sill (Fig. 1). The region experiences a pronounced seasonal climate with a wet monsoon from November to March and dry southeasterly trade winds from May to September. The shelf is occasionally affected by tropical cyclones that mobilize sediment and may affect the associated benthos. The region has been greatly influenced by Late Quaternary sea level changes and sedimentary discharges from rivers in northern Australia and Papua New Guinea such that modern-day sediments in both areas comprise mainly poorly-sorted terrigenous and carbonate muddy sands (Heap et al. 2004). Present-day, fully-open marine conditions were established in the GoC only about 9-10,000 years ago following inundation of the Arafura Sill approximately 12,000 years ago; prior to that, at least to about 70,000 years ago, the GoC was above sea level and was represented by a large fresh to brackish water lake (Lake Carpentaria) of varying extent (Torgersen et al. 1988; Yokoyama et al. 2001; Heap et al. 2004). During this glacial period of low sea level the Arafura Sill would have corresponded to a delta for Lake Carpentaria and its drainage system, with terrigenous sediments passing through it and ultimately into the Arafura Sea. Seaward of the Sill are a series of now submerged ridges and valleys (Fig. 1). Thus the GoC and adjacent Arafura Sea share a similar sedimentary environment as a result of a common paleo-drainage system; however, the history of the biota inhabiting the sediments in the two regions is likely to be very different - GoC marine species have been there for less than 10,000 years but species inhabiting the northern Arafura Sea could be much older as marine conditions persisted there during periods of low sea level.

The pilargid fauna analyzed in this study were collected from several different studies over a 40year period from six different sites, including offshore sites in the Arafura Sea, GoC and inshore sites at Gove and MacArthur River (Fig. 2). These sites represent four distinct geomorphic units: outer shelf ridge and valleys (site 1), shelf (sites 5,6), bank/shoals (site 3), and inshore sites that may have seagrass beds and seasonally lowered salinity (sites 2, 4). [The first three geomorphic units are based on Heap et al. (2004)].

This study aims to document the pilargid fauna of the GoC-Arafura Sea region and characterize each species in terms of its geomorphic, sediment, and depth preferences. Also we review the present-day distribution of each species, and based on distributional, ecological, and geological data, suggest possible historical scenarios for the post-glacial colonization of the GoC by Pilargidae.

\section{Materials and methods}

Specimen and sediment collections. Pilargid specimens were reviewed from survey collections over the last 40 years (mostly the last 18 years), including samples from the Arafura Sea, Gove, McArthur River and the Gulf of Carpentaria. The Arafura Sea samples were collected in May 2005 on the R.V. Southern Surveyor cruise 05-2005 (Wilson 2006). The GoC benthic invertebrates were collected in February-March 2005 on the Southern Surveyor cruise 03-2005; this cruise sampled in the vicinity of Groote Eylandt and the Vanderlins and Mornington Island groups. The specimens from Gove and McArthur River were collected as part of NTM benthic baseline surveys conducted at the ports of Melville Bay (July 1991, March 1992, March 1993) and Bing Bong (March 1993), respectively. Identifications were verified and standardized across all surveys based on recent generic revisions. Specimens examined are housed at the Museum and Art Gallery of the Northern Territory, Darwin (NTM) and Queensland Museum, Brisbane (QM). Type material of Sigambra pettiboneae Hartmann-Schröder, 1979 from the Zoologisches Institut und Zoologisches Museum der Universität Hamburg, Germany (HZM) was also examined. 


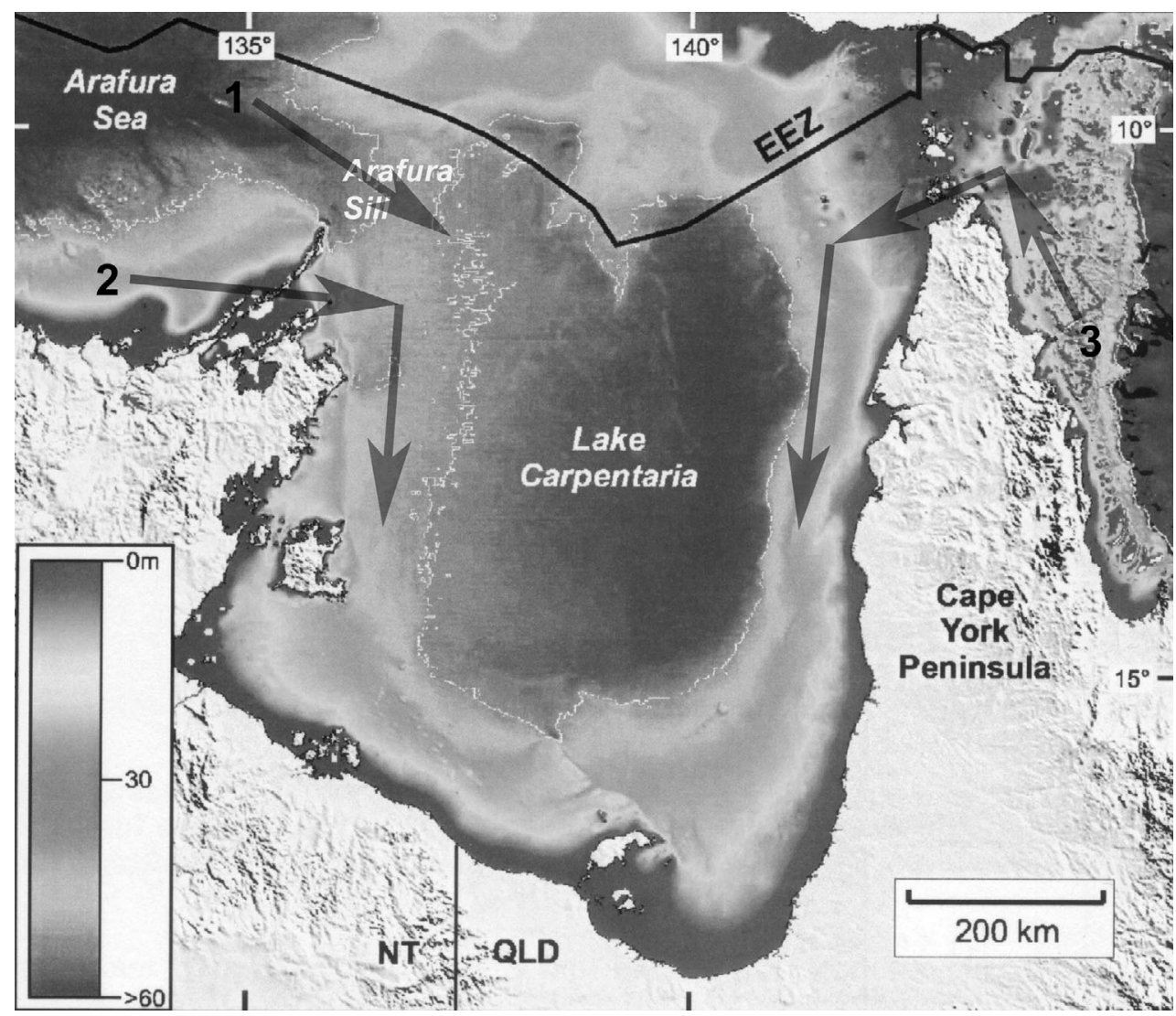

FIGURE 1. False-color image showing a period about 23, 000 to 26,000 years ago when the sea level was about $65 \mathrm{~m}$ below its current level and Lake Carpentaria had reached its maximum extent within the area known at present day as GoC. The arrows indict possible tracks for colonization of pilargid species into the GoC as sea level rose to its present position. See text for explanation. Modified from Heap et al. (2004).

Sediment grain size data for the Arafura Sea were supplied by the Marine Sediment Database (Geosciences Australia 2006). The GoC sediment data were collected and analyzed by Geosciences Australia at the time of benthic invertebrate collection in 2005.

Data Analysis. Sediment preferences for 10 of the 13 pilargid species were determined statistically (Pilargis sp. 1, Sigambra cf. robusta and Sigambra sp. 'arafura' were not analyzed because they were represented by only one or a few specimens). Sediment grain size data (\% mud, sand, and gravel) was analyzed using a covariance-based PCA utilizing PAST software (Hammer 2001). A total of 146 stations were represented in the plots from Arafura Sea, Gove, McArthur River, and the GoC (Groote Eylandt, Vanderlins and Mornington). Species occurrence data were reduced to presence/absence (i.e., abundances removed) because of the differing sampling techniques used across the surveys. 


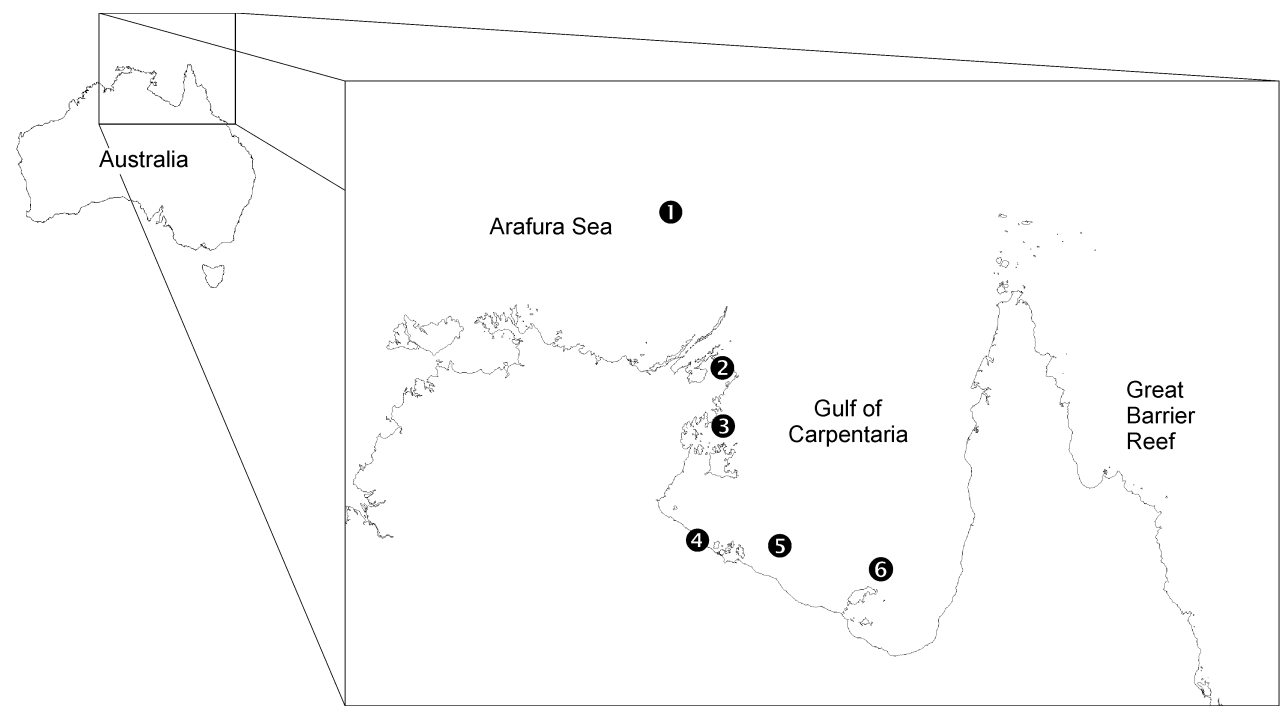

FIGURE 2. Location of pilargid material identified in this study, including Arafura Sea (1); inshore sites at Gove (2) and McArthur River (4); and three locations in the Gulf of Carpentaria: Groote Eylandt (3), Vanderlins (5), Mornington Islands (6).

\section{Results}

\section{Taxonomy}

Pilargidae de Saint-Joseph, 1899

Pilarginae de Saint-Joseph, 1899

\section{Ancistrosyllis McIntosh, 1879}

Ancistrosyllis cf. hartmanae Pettibone, 1966

Material examined. NTM (W7799, W16798, W16799, W16800, W16801, W16802, W16803, W16804, W16806, W16807, W16808, W16809, W16810, W016811, W16812, W16813, W16814, W16815, W16816, W16817).

Location. Gove, McArthur River (Table 1).

Remarks. Ancistrosyllis, as currently defined, is one of a few genera of Pilargidae (indeed Phyllodocida) that have a variable number of prostomial antennae: the 14 currently valid species may have either one, two, or three antennae (Fiege \& Böggemann 1999). The Ancistrosyllis specimens collected in this study belong to the group having three antennae. In particular they are similar to A. hartmanae, originally described from Chesapeake Bay, USA, in having both ventral cirri and notopodial hooks from the third chaetiger. They differ from A. hartmanae however in having dorsal body papillae, or verrucae (new term suggested by Salazar-Vallejo \& Harris 2006), arranged in distinct transverse rows (especially anteriorly_papillae are less dense posteriorly), and the lateral antennae being about three times longer than the median one. This genus is currently poorly represented in the Indo-West Pacific, but this record and two different forms from the Solomon Islands (G. Read pers. com.) suggest that several undescribed species, including this one, occur here. 
TABLE 1. Occurrence of pilargid species in the four main study areas in northern Australia and extralimitally. $(x)$ Absent, $(\checkmark)$ Present, N/A = Not Available.

\begin{tabular}{llllll}
\hline & & Gulf of & \multicolumn{3}{l}{ McArthur } \\
Species & Arafura Sea & Carpentaria & Gove & River & Extralimital \\
\hline Ancistrosyllis cf. hartmanae & $\times$ & $\times$ & $\checkmark$ & $\checkmark$ & N/A \\
Cabira sp.1 & $\checkmark$ & $\checkmark$ & $\checkmark$ & $\checkmark$ & N/A \\
Litocorsa annamita & $\checkmark$ & $\checkmark$ & $\times$ & $\times$ & Vietnam, South China Sea \\
Litocorsa sp. 'arafura' & $\checkmark$ & $\times$ & $\times$ & $\times$ & N/A \\
Loandalia gladstonensis & $\times$ & $\checkmark$ & $\checkmark$ & $\checkmark$ & Gladstone, Qld \\
Pilargis sp. 1 & $\times$ & $\checkmark$ & $\times$ & $\times$ & N/A \\
Sigambra cf. robusta & $\times$ & $\times$ & $\checkmark$ & $\times$ & N/A \\
Sigambra sp. 2 & $\times$ & $\checkmark$ & $\checkmark$ & $\checkmark$ & Cairns, Brisbane, Qld \\
Sigambra sp. 'arafura' & $\checkmark$ & $\times$ & $\times$ & $\times$ & N/A \\
Sigambra cf. tentaculata & $\checkmark$ & $\checkmark$ & $\checkmark$ & $\checkmark$ & N/A \\
Sigambra pettiboneae & $\times$ & $\times$ & $\checkmark$ & $\checkmark$ & Broome, NW Australia \\
Synelmis gibbsi & $\checkmark$ & $\times$ & $\times$ & $\times$ & Indo-west Pacific, ?Red Sea \\
Synelmis cf. rigida & $\checkmark$ & $\checkmark$ & $\times$ & $\times$ & Central and West Pacific \\
\hline
\end{tabular}

Cabira Webster, 1879

Cabira sp. 1

Material examined. QM (GOCI01000008, GOCI01000012, GOCI01000020, GOCI01000029, GOCI01000046, GOCI01000047, GOCI01000061, GOCI01000065). NTM (W534, W584, W585, W586, W587, W589, W590, W591, W593, W594, W653, W1977, W2002, W7801, W8230, W16818, W16819, W16820, W16821, W16822, W21889, W21890, W21891, W21892, W21893, W21894, W21895).

Location. Arafura Sea; Gove, McArthur River and GoC (Table 1).

Remarks. Cabira currently contains six species/subspecies (Mandal et al. 2007). Unlike other pilargid genera, the parapodia on which the first notopodial hooks occur is quite conservative among species (range, typically chaetigers 6-8); in our specimens the range was also chaetigers 6-8. The present specimens appear to differ from other species in the genus in having smooth tapered neurochaetae of two different lengths, a body divided by a constriction into a short 'thorax' and longer 'abdomen', which often displayed marked beading of segments, and the parapodia and dorsal cirri which lacked verrucae unlike the rest of the dorsum. Also, some specimens had distinctive subcutaneous brown pigments spots on the abdomen like some species of Pilargis (Salazar-Vallejo \& Harris 2006).

\section{Pilargis Saint-Joseph, 1899}

Pilargis sp. 1

Material examined. NTM W21896.

Location. Mornington Island, GoC (Table 1).

Remarks. The single specimen found in this study confirms the observation of Salazar-Vallejo \& Harris (2006) that Pilargis are not common. We are unable to assign it to species at this time. This species appears to be rare in space/time and is therefore not included in the discussion of ecology. 


\section{Sigambra Müller, 1858}

\section{Sigambra pettiboneae Hartmann-Schröder, 1979}

Type material examined. Holotype (HZM P-16826), paratypes 4(HZM P-15498)

Other material examined. NTM (W7798, W16582, W16584, W16586, W16587, W16589, W16590, W16592, W16593, W16594, W16595, W16596, W16597, W16599, W16600, W16601, W16603, W16604, W16605, W16607, W16610, W16611, W16614, W16615, W16616, W16620, W16621, W16624, W16629, W16630, W16639, W16643, W16653, W16668, W16671, W16672, W16673, W16676, W16680, W16683, W16687, W16690, W16692, W16693, W16696, W16697, W16699, W16716, W16717, W16718, W16720, W16727, W16740, W16763, W16764).

Location. Gove and McArthur River (Table 1).

Remarks. As this is one of only a few pilargid species originally described from the region (type locality: Broome, NW Australia), the types were reexamined and compared to the study specimens. The type material had a moderately long median antenna (1.5-2.0x length of laterals), chaetiger 2 lacked ventral cirri, dorsal cirri were approximately $2 \times$ longer than the ventral cirri, and the pharynx had approximately 14 distal papillae encircling its rim. Interestingly, the start of the notopodial hooks showed significant variation ranging from chaetiger 8 (holotype, large specimen) to chaetiger 14 (paratypes, smaller specimens). Specimens from Gove and MacArthur River compared well with the type material in all characters; the notopodial hooks started from chaetigers 7-16.

\section{Sigambra cf. robusta (Ehlers, 1908)}

Material examined. NTM W16755

Location. Gove (Table 1).

Remarks. The single specimen found in this study is tentatively identified as $S$. cf. robusta. It differed from other Sigambra found in this study in having a ventral cirrus on chaetiger 2 (but only on one side), a median antenna about $1.5 \times$ the length of the lateral antenna, dorsal cirri about $2 \times$ longer than ventral cirri, about 8 distal pharyngeal papillae, and notopodial hooks from about chaetiger 23. This species appears to be rare in space/time and is therefore not included in the discussion of ecology.

\section{Sigambra cf. tentaculata (Treadwell, 1941)}

Material examined. QM (GOCI01000010, GOCI01000023, GOCI01000028, GOCI01000032, GOCI01000034, GOCI01000038, GOCI01000041, GOCI01000043, GOCI01000051, GOCI01000054, GOCI01000057, GOCI01000059, GOCI01000060, GOCI01000062, GOCI01000064, GOCI01000068, GOCI01000074, GOCI01000075, GOCI01000077, GOCI01000080, GOCI01000082, GOCI01000083, GOCI01000084, GOCI01000085, GOCI01000086, GOCI01000087). NTM (W16591, W16642, W16659, W16669, W16675, W16679, W16681, W16682, W16689, W16695, W16698, W16700, W1671, W16704, W16705, W16706, W16707, W16708, W16709, W16711, W16713, W16714, W16715, W16721, W16725, W16732, W16733, W16736, W16742, W16744, W16745, W16748, W16749, W16752, W16753, W16758, W16759, W16767, W16768, W16772, W16783, W16785, W16793, W16794, W21897, W21898, W21899, W21900, W21901, W21902, W21903, W21904, W21905, W21906, W21907, W21908, W21909, W21910, W21911, W21912, W21913, W21914, W21915, W21916, W21917, W21918, W21919, W21920, W21921, W21922, W21923, W21924, W21925, W21926, W21927, W21928, W21929, W21930, W21931, W21932, W21933, W21934, W21935, W21936, W21937, W21938, W21939, W21940).

Location. Arafura Sea; Gove, McArthur River and GoC (Table 1).

Remarks. Moreira \& Parapar (2002) redescribed the holotype of Sigambra tentaculata, which is from Long Island, New York. The specimens from this study generally fit the description of these 
authors, although the characteristic pharyngeal papillation (tooth-like papillae and distal papillae) could not be properly assessed as most specimens had their pharynx retracted. A recent publication by Nishi et al. (2007) reestablished S. hanaokai (Kitamori, 1960), which was previously considered to be a junior synonym of $S$. tentaculata (Treadwell, 1941). Unfortunately due to time restrictions it was not possible to compare material of $S$. hanaokai with our specimens. Future studies comparing the present material with S. tentaculata and other similar species (S. parva Day, 1963 and $S$. hanaokai) are planned.

\section{Sigambra sp. 2}

Material examined. QM (GOCI01000022, GOCI01000039, GOCI01000058). NTM (W8226, W16608, W16628, W16635, W16637, W16650, W16654, W16684, W16688, W16691, W16702, W16710, W16724, W16737, W21941).

Location. Gove, McArthur River, and GoC (Table 1).

Remarks. Sigambra sp. 2 is closest to Sigambra cf. tentaculata but differs from this species in having only 8-12 distal pharyngeal papillae (S. cf. tentaculata has 14), and in having the first dorsal cirrus equal in length to the peristomial cirri ( $S$. cf. tentaculata has the first dorsal cirrus about 1.2-1.5 $\times$ longer than the peristomial cirri). This species has also been recorded from Brisbane and Cairns, Queensland (SAM, pers. obs.).

\section{Sigambra sp. 'arafura'}

Material examined. NTM W21942

Location. Arafura Sea (Table 1).

Remarks. This is an unusual, probably new, species of Sigambra characterized by having a median antenna that is several times (4-5) longer then the laterals, lacking a ventral cirrus on chaetiger 2, dorsal cirri only slightly larger than ventral cirri, and notopodial hooks occurring only on posterior chaetigers (after chaetiger 40). In this last feature it resembles S. rugosa Fauchald, 1972 and $S$. robusta (Ehlers, 1908), but the former has a much shorter median antenna and the latter has ventral cirri on chaetiger 2. It bears slightly less similarity to Sigambra sp. 3 reported from the South China Sea by Al-Hakim \& Glasby (2004).

Synelminae Salazar-Vallejo, 1987

Litocorsa Pearson, 1970

Litocorsa annamita (Gallardo, 1968)

Material examined. QM (GOCI01000002, GOCI01000004, GOCI01000005, GOCI01000011, GOCI01000015, GOCI01000024, GOCI01000027, GOCI01000030, GOCI01000033, GOCI01000044, GOCI01000048, GOCI01000050, GOCI01000052, GOCI01000053, GOCI01000055, GOCI01000056, GOCI01000063, GOCI01000066, GOCI01000067, GOCI01000069, GOCI01000070, GOCI01000072, GOCI01000078, GOCI01000088, GOCI01000306. NTM (W21943, W21944, W21945, W21946, W21947, W21948, W21949, W21950, W21951, W21952, W21953, W21954, W21955, W21956, W21957, W21958, W21959, W21960, W21961, W21962, W21963, W21964, W21965, W21966, W21967, W21968, W21969).

Location. Arafura Sea and GoC (Table 1).

Remarks. The genus Litocorsa has not been reviewed recently, and therefore species allocation is difficult. The above specimens have been tentatively identified as L. annamita based on the presence of three antennae, smooth neurospines (without arista or subterminal teeth) first present in median chaetigers, and notospines first emerging from chaetiger 12-14. This species was originally described from Vietnam, but is now known to occur throughout the South China Sea (Al-Hakim \& Glasby 2004). 
Litocorsa sp. 'arafura'

Material examined. NTM ( W21970, W21971, W21972, W21973, W21974, W21975, W21976, W21977, W21978.

Location. Arafura Sea (Table 1).

Remarks. This species is most probably undescribed. It seems to be closest to L. acuminata (Wolf, 1986) in having an anterior cleft between the palps, notospines from about chaetiger 5-6, and aristate neurospines; however, the present material differs from this species in that the neurospines are tridentate and they start from chaetiger 20-26 rather than from chaetiger 15-18 (see Darbyshire \& Mackie 2003).

\section{Loandalia Monro, 1936}

Loandalia gladstonensis Marks \& Hocknull, 2006

Material examined. QM (GOCI01000001, GOCI01000003, GOCI01000006, GOCI01000007, GOCI01000009, GOCI01000013, GOCI01000014, GOCI01000016, GOCI01000017, GOCI01000018, GOCI01000019, GOCI01000021, GOCI01000025, GOCI01000026, GOCI01000031, GOCI01000035, GOCI01000036, GOCI01000037, GOCI01000040, GOCI01000042, GOCI01000045, GOCI01000049). NTM (W592, W7800, W8229, W16823, W16824, W16825, W16826, W16827, W16828, W16829, W16830, W16831, W16832, W16833, W16834, W16835, W16836, W16837, W16838, W16839, W16840, W16841, W16842, W16843, W16844, W16845, W16846, W16847, W16848, W16849, W16850, W16851, W16852, W16853, W16854, W16855, W16856, W21979, W21980, W21981).

Location. Gove, McArthur River, and GoC (Table 1).

Remarks. The material examined in this study extends the distribution of this species, which was previously known only from Gladstone, Queensland. In general the specimens fit within the variation range described for this species. The only differences appear to be the presence in some specimens of additional minute subdermal eyespots (which appear to correspond to paired pigment spots on the hind, mid and anterior brain) and a pair of large eyespots (or pigment patches) on the anal plate.

\section{Synelmis Chamberlin, 1919}

Synelmis gibbsi Salazar-Vallejo, 2003

Material examined. NTM (W21982, W21983, W21984, W21985, W21986).

Location. Arafura Sea (Table 1).

Remarks. The present material fits within the variation range described for this species by Salazar-Vallejo (2003). It can be easily distinguished from the other species of Synelmis found in the study, S. rigida, by the earlier start of the notospines (chaetiger 5 vs. chaetigers 11-19) and the presence of a pair of eyes, which sometimes appear as two pairs of closely set eyes (absent in $S$. rigida) This species is widespread in the Indo-West Pacific and questionably also occurs in the Red Sea (Salazar-Vallejo 2003).

\section{Synelmis cf. rigida (Fauvel, 1919)}

Material examined. QM (GOCI01000073, GOCI01000076, GOCI01000081). NTM (W21987, W21988, W21989, W21990, W21991, W21992, W21993, W21994).

Location. Arafura Sea and GoC (Table 1).

Remarks. The present material fits within the variation range described for this species by Salazar-Vallejo (2003), except for the presence of eyespots which are lacking in the present material but said to be present in S. rigida. For this reason, and the fact that our material also fits the description of the poorly known species S. sinica Sun and Chen, 1990 (type locality, South China 
Sea), we tentatively identify it as $S$. $c f$. rigida. The present material should, however, be compared with the types of $S$. sinica. Synelmis rigida has previously been reported in the tropical Central and West Pacific (Salazar-Vallejo 2003). The present record extends its distribution westward to northern Australia.

\section{Ecology}

In total, 572 specimen lots (comprising one to several specimens per lot) of pilargids, comprising 90 lots from the Arafura Sea, 293 lots from the GoC, 143 from Gove, and 46 from McArthur River, were examined and identified to species or species units. Individuals were assigned to 13 species (or species units) and seven genera. Although all four localities have a similar diversity of species (6-7 species each), the species composition differs between each region. Table 1 lists all 13 species and their presence or absence from each of the four locations, and whether or not the species has been reported outside the study areas.

Several species currently appear to be endemic at the regional level: Litocorsa sp. 'arafura' and Sigambra sp. 'arafura' were collected only from the Arafura Sea, Pilargis sp. 1 was collected only within the GoC, and Sigambra cf. robusta was only collected from Gove. Although Synelmis gibbsi was only reported from the Arafura Sea stations in this study, the species is known to be widely distributed in the Central and West Pacific. Two species were present in all sampled locations: Cabira sp. 1 and Sigambra cf. tentaculata.

The habitat of pilargid fauna can be partitioned into three components: (1) a deep continental shelf component with a depth of 69-233 m characteristic of the Arafura Sea-includes ridges and valleys; (2) a shallow continental shelf component with a depth of 26-52 m characteristic of the GoC regions-includes banks and shoals, and (3) an inshore component with seagrasses and seasonally lowered salinity and a depth of 0.5-15 m characteristic of the Gove and McArthur River regions. Three species, Ancistrosyllis cf. hartmanae, Sigambra cf. robusta and Sigambra pettiboneae appear to be found solely in the inshore habitat; Synelmis cf. rigida and Litocorsa annamita appear to be offshore generalists occurring in both the Arafura Sea and GoC in a range of depths between 26 and 233 m; and Litocorsa sp. 'arafura', Sigambra sp. 'arafura' and Synelmis gibbsi are offshore species occurring only in the Arafura Sea, at depths between 69 and $233 \mathrm{~m}$.

Figs. 3-4 show the sediment-based PCA plots with the presence/absence of each pilargid species represented by the filled squares and cross symbols respectively. The majority of the species are found in all sediment types from high percentage of gravel to high percentage of mud. However, three species appear to have more selective grain size preferences: Litocorsa sp. 'arafura' and Synelmis gibbsi are found in sand and gravel dominated sediments, and Ancistrosyllis cf. hartmanae is the only species found in mud and sand dominated sediments. All PCAs shown in Figs. 3-4 are represented by a variance of $83.26 \%$ for PC1 and a variance of $16.72 \%$ for PC2.

\section{Discussion}

The results of this study need to be viewed within the context of the following limitations. Despite our efforts to standardize data across all surveys by removing abundance data (as different sampling techniques were used), there still remains the possibility that the data could be affected by differences in collection time, viz. annual and seasonal variation was not accounted for. This is probably more problematical for the inshore sites (Gove and McArthur River), as shallow water benthic fauna could be more affected by storms and cyclones than deep shelf fauna. A seasonal cycle 
of polychaete occurrence and abundance has been reported for intertidal sites in Darwin Harbour (Metcalfe \& Glasby 2008). However, despite these limitations, we believe that the large number of samples analyzed provides us with reasonable confidence that at each site the pilargid fauna was reasonably comprehensively sampled.
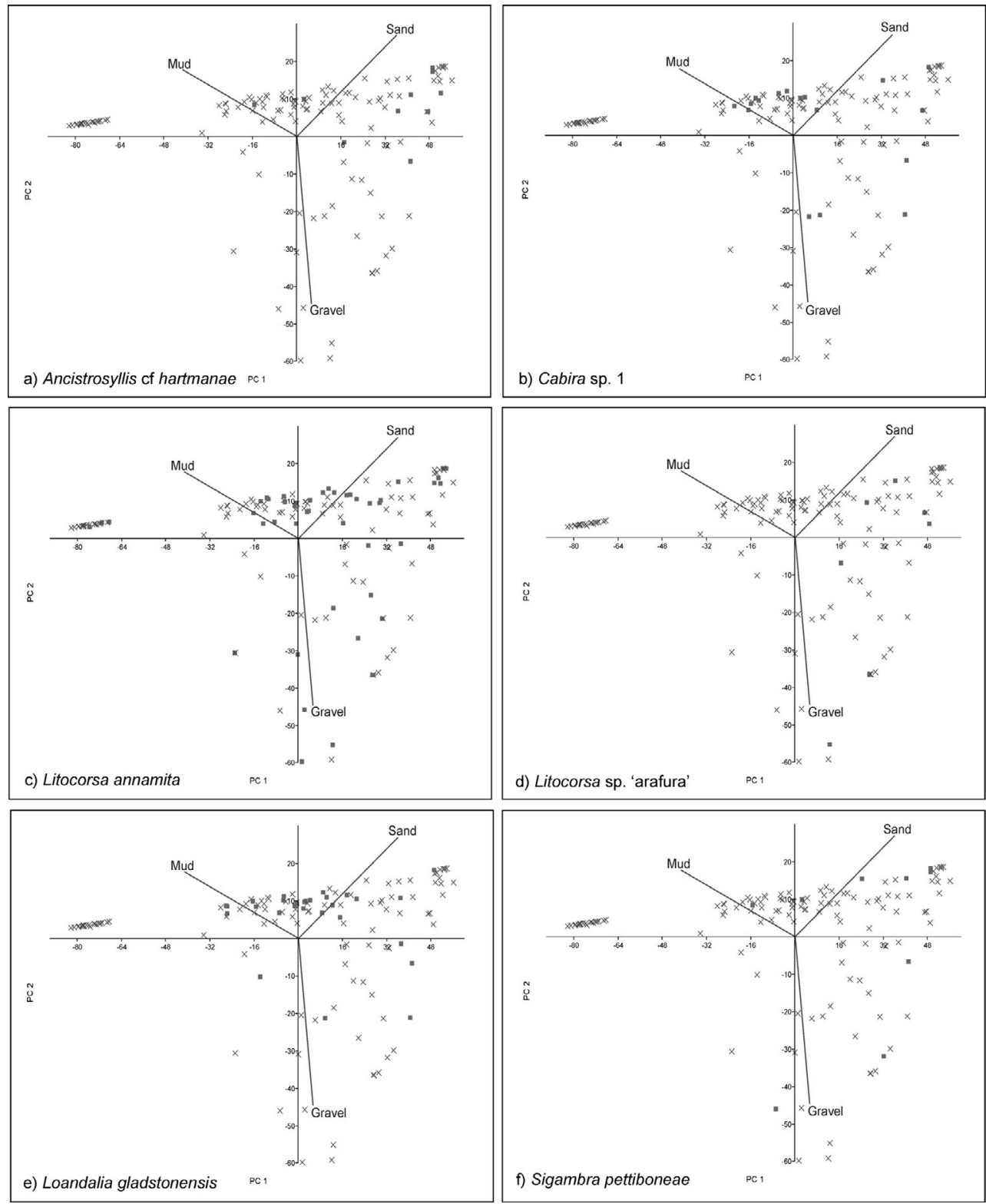

FIGURE 3. Principal Component Analysis (PCA) of sediment grain size for Arafura Sea and the GoC locations. PCAs are represented by a combined variance of $99.98 \%$ for PC1 and PC2. For the six species shown, green cross $=$ absence of species from site and pink filled square $=$ presence of species at site. 

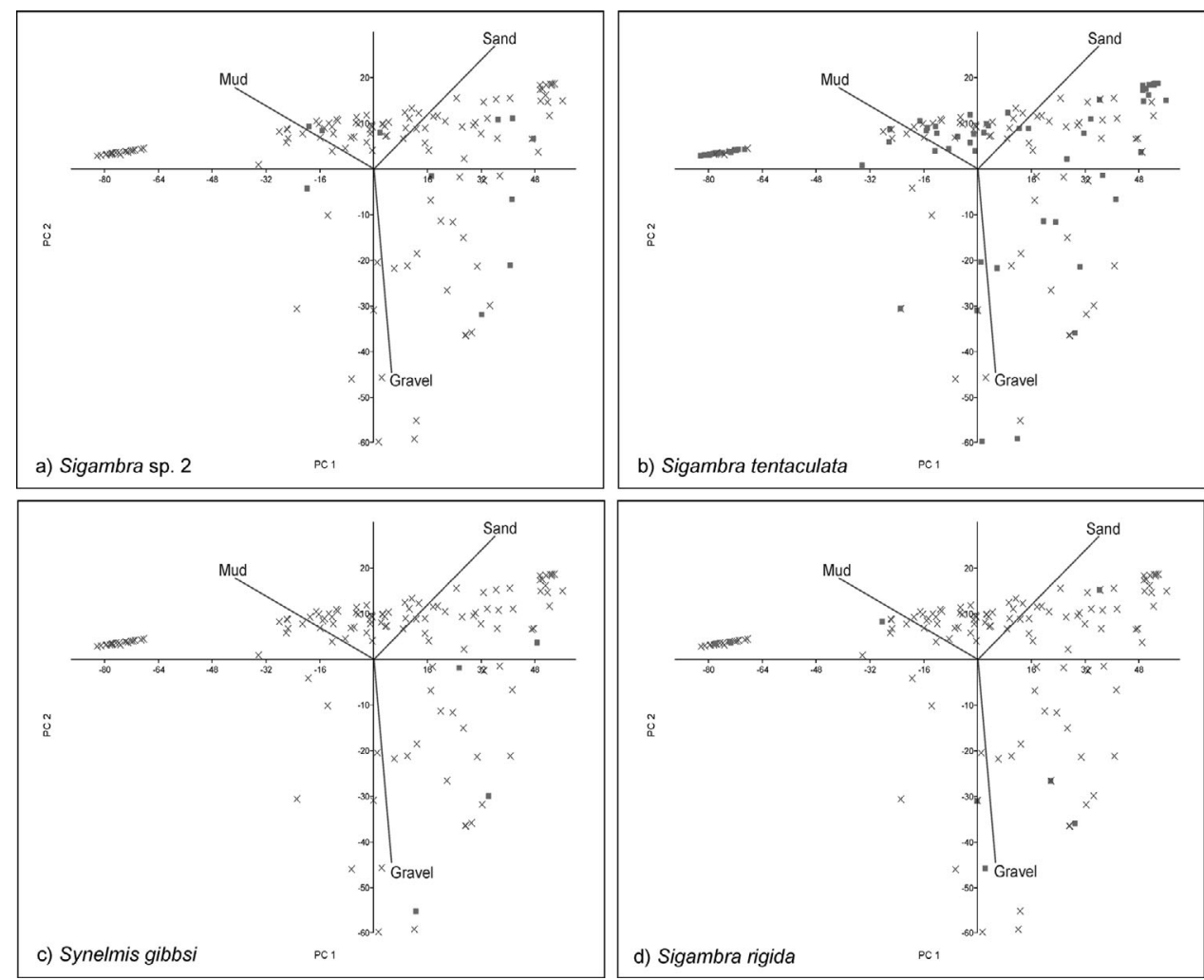

FIGURE 4. Principal Component Analysis (PCA) of sediment grain size for Arafura Sea and the GoC locations. PCAs are represented by a combined variance of $99.98 \%$ for PC1 and PC2. For the four species shown, green cross $=$ absence of species from site and pink filled square $=$ presence of species at site.

Diversity and Endemism. Niche preference of pilargids can be described through a number of environmental characteristics, including depth, sediment type, and geomorphic unit (Table 2). Together with the information on the occurrence of each species at each of the four locations (Table 1), we can draw some preliminary conclusions on the degree of endemism of each species and routes (tracks) of post-glacial colonization of the GoC, as follows:

1) Widespread generalists-found at all locations, in all sediment types (Cabira sp. 1 and Sigambra cf. tentaculata); widespread post-glacial colonization of GoC

2) Offshore-only widespread generalists - found in the Arafura Sea and Gulf of Carpentaria, in all sediment types (Litocorsa annamita and Synelmis cf. rigida); both species also occur in the South China Sea; limited post-glacial colonization of GoC (track 1, Fig. 1)

3) Endemic to inshore habitats of northern Australia - found in Gove and McArthur River, with Ancistrosyllis cf. hartmanae being unique to mud and sand dominated sediments, and Sigambra pettiboneae collected from all sediment types; S. pettiboneae also occurs in northwest Australia; possible eastward shoreline colonization of GoC (track 2, Fig. 1)

4) Endemic to northeastern Australia - found on the shelf and in the inshore habitats of the GoC and Queensland, includes Loandalia gladstonensis and Sigambra sp. 2; possible westward shoreline colonization of GoC (track 3, Fig. 1) 
5) Endemic to the Arafura Sea-found only in the Arafura Sea, with sediment dominated by sand and gravel includes Litocorsa sp. 'arafura', Sigambra sp. 'arafura' (although Synelmis gibbsi also occurs in the Arafura Sea it has been reported more widely in the Indo-West Pacific). Litocorsa sp. 'arafura' appears to occupy a similar ecological niche as the Gulf of Mexico species, Litocorsa stremma Pearson, 1970, which is known to prefer near shore sandy sediments with a relatively low mud content (Flint \& Rabalais 1980) and is thought to be a scavenger (Pearson 1970).

The high diversity and endemism of Pilargidae in the epicontinental seas of northern Australia is most likely attributable to a favorable prograding sedimentary environment that existed during the Quaternary and beyond, its position between the Pacific Ocean and Indian Ocean (via Arafura Sea), and the shallowness of the region (esp. the Gulf of Carpentaria), which combined with fluctuations in sea level would have promoted speciation. A comparable level of diversity has been found in Mexico, which has 14 species and seven genera (Salazar-Vallejo 1987), but this count includes both the east and west coasts of Mexico, and therefore does not represent a single epicontinental sea as does the region considered here. Further studies are required in order to corroborate the patterns found here. In particular, more environmental data and taxonomic clarity is required for species occurring not only in northern Australian waters, but also those surrounding areas.

TABLE 2. Habitat preference of pilargids from northern Australia locations. *Data not quantifiable as only one individual specimen of this species has been collected.

\begin{tabular}{llll}
\hline Species & Geomorphic unit & Depth range (m) & Sediment type \\
\hline Ancistrosyllis cf. hartmanae & Inshore & $0.5-15$ & Mud / Sand \\
Cabira sp.1 & Inshore, Sill and canyon, Shelf, & $0.5-233$ & Mud / sand / gravel \\
Litocorsa annamita & Bank and shoals? & Sill and canyon, Bank and shoals? 26-52 & Mud / sand / gravel \\
Litocorsa sp. 'arafura' & Sill and canyon & $69-233$ & Sand \& gravel \\
Loandalia gladstonensis & Inshore, Shelf, Bank, and shoals? & $0.5-52$ & Mud / sand / gravel \\
Pilargis sp. 1 & Bank and shoals? & $26-52$ & N/A* \\
Sigambra cf. robusta & Inshore & $5-15$ & N/A* \\
Sigambra sp. 2 & Inshore, Shelf, Bank, and shoals? & $0.5-52$ & Mud / sand / gravel \\
Sigambra sp. 'arafura' & Sill and canyon & $69-233$ & N/A* \\
Sigambra cf. tentaculata & Inshore, Shelf, Bank, and shoals? & $0.5-233$ & Mud / sand / gravel \\
Sigambra pettiboneae & Inshore & $0.5-15$ & Mud / sand / gravel \\
Synelmis gibbsi & Sill and canyon & $69-233$ & Sand \& gravel \\
Synelmis cf. rigida & Shelf, Bank, and shoals? & $26-52$ & Mud / sand / gravel \\
\hline
\end{tabular}

\section{Acknowledgments}

We thank staff of Geosciences Australia for the collation and laboratory analysis of sediment samples. SM thanks Rodrigo Bustamante of CSIRO Marine and Atmospheric Research for making 
available the pilargid specimens and sediment data collected through the Northern Prawn Fisheries Benthos Project (a project of the Fisheries Research and Development Corporation FRDC, and Marine National Facility). SM thanks Scott Hocknull, David Dique, Shireen Fahey, GHD Business School, the Australian Biological Resources Studies (ABRS) and Ausproof Pty. Ltd for support to attend and present this research at the Ninth International Polychaete Conference in Portland, Maine, August 2007.

\section{References}

Al-Hakim, I. \& Glasby, C.J. (2004) Polychaeta (Annelida) of the Natuna Islands, South China Sea. Raffles Bulletin of Zoology Supplement, 11, 25-45.

Chamberlin, R.V. (1919) The Annelida Polychaeta of the Albatross Tropical Pacific Expeditions, 1891-1905. Memoirs of the Museum of Comparative Zoology Harvard University, 48, 1-514.

Darbyshire, T. \& Mackie, A.S.Y. (2003) Species of Litocorsa (Polychaeta: Pilargidae) from the Indian Ocean and South China Sea. Hydrobiologia, 496, 63-73.

Day, J.H. (1963) The polychaete fauna of South Africa Part 8. New species and records from grab samples and dredgings. Bulletin of the British Museum (Natural History) (Zoology), 10, 383-445.

Ehlers, E. (1908) Die bodensaessigen Anneliden aus den Sammlungen der deutschen Tiefsee-Expetition. Wissenschaftliche Ergebnisse der deutschen Tiefsee-Expedition au dem Dampfer Valdivia, 16, 1-169.

Fauchald, K. (1972) Benthic polychaetous annelids from deep water off Western Mexico and adjacent areas in the Eastern Pacific Ocean. Allan Hancock Monographs in Marine Biology, 7, 1-575.

Fauvel, P. (1919) Annélida polychètes des îles Gambier et Touamotu. Bulletin du Muséum national d'Histoire naturelle, 25, 336-343.

Fiege, D. \& Böggemann, M. (1999) Ancistrosyllis fioronii, a new species of Pilargidae from the North Sea, with a key and synoptic table of characters for all species of the genus Ancistrosyllis McIntosh 1879 (Annelida, Polychaeta, Pilargidae). Senckenbergiana Biologica, 78(1/2), 135-140.

Flint, R.W. \& Rabalais, N.N. (1980) Polychaete ecology and niche patterns: Texas continental shelf. Marine Ecology Progress Series, 3(3), 193-202.

Gallardo, V.A. (1968) Polychaeta from the Bay of Nha Trang, South Vietnam. Naga Report, 4(3), 35-279.

Geosciences Australia (2006) Marine sediments database. Available from: http://www.ga.gov.au/oracle/mars/ (accessed 29 December 2007).

Glasby, C.J. (2000) Family Pilargidae. In: Beesley, P.L., Ross, G.J.B. \& Glasby, CJ. (Eds), Polychaetes \& Allies. The Southern Synthesis. Fauna of Australia Vol. 4A Polychaeta, Myzostomida, Pogonophora, Echiura, Sipuncula. CSIRO Publishing, Melbourne, pp. 148-150.

Hammer, O., Harper, D.A.T. \& Ryan, P.D. (2001) PAST: Paleontological Statistics Software Package for Education and Data Analysis. Palaeontologia Electronica, 4(1), 9 pp.

Available from http://palaeo-electronica.org/2001_1/past/issue1_01.htm (accessed 12 December 2007)

Hartmann-Schröder, G. (1979) Die Polychaeten der tropischen Nordwestküste Australiens (zwischen Derby im Norden und Port Hedland im Süden). In: Hartmann-Schröder, G. \& Hartmann, G. (Eds.), Zur Kenntnis des Eulitorals der australischen Küsten unter besonderer Berücksichtigung der Polychaeten und Ostracoden, Teil 2. Mitteilungen aus dem Hamburgischen Zoologischen Museum und Institut, 76, 75-218.

Heap, A., Daniell, J., Mazen, D, Harris, P., Sbaffi, L., Fellows, M. \& Passlow, V. (2004) Geomorphology and sedimentology of the northern marine planning area of Australia: review and synthesis of relevant literature in support of regional marine planning. Geosciences Australia, record 2004/11. pp. 68.

Kitamori, R. (1960) Description of two new species of Pilargiidae (Annelida: Polychaeta) from the Seto Inland Sea. Bulletin of the Japanese Society of Scientific Fisheries, 26, 1086-1090.

Long, B.G. \& Poiner, I.R. (1994) Infaunal benthic community structure and function in the Gulf of Carpentaria, 
northern Australia. Australian Journal of Marine and Freshwater Research, 45, 293-316.

Mandal, S., Harkantra, S.N. and Salazar-Vallejo, S.I. (2007) Cabira rangarajani n. sp. (Polychaeta: Pilargidae) from the Goa coast, central west coast of India. Zootaxa, 1446, 21-29.

Marks, S.A. \& Hocknull, S.A. (2006) New species of Loandalia (Polychaeta: Pilargidae) from Queensland, Australia. Zootaxa, 1119, 59-68.

McIntosh, W.C. (1879) On the Annelida obtained during the cruise of H.M.S. Valorous to Davis Strait in 1875. Transactions of the Linnean Society of London, new series, 1, 499-511.

Metcalfe, K. \& Glasby, C.J. (2008) Diversity of Polychaeta (Annelida) and other worm taxa in mangrove habitats of Darwin Harbour, northern Australia. Journal of Sea Research, 59, 70-82.

Monro, C.C.A. (1936) Polychaete worms. Discovery Report, 12, 59-198.

Moreira, J. \& Parapar, J. (2002) Redescription of Sigambra tentaculata and re-establishment of S. parva (Polychaeta, Pilargidae) based upon type material. Cahiers de Biologie Marine, 43, 99-109.

Müller, F. (1858) Einiges Über die Annelidenfauna der Insel Santa Catharina an der brasilisnischen Küste. Archiv für Naturgeschichte, 24, 211-220.

Nishi, E., Tanaka, K., Fujioka, Y. \& Sato, M. (2007) Reinstatement of Sigambra hanaokai (Kitamori, 1960) (Polychaeta, Pilargidae) with an overview of the literature on the genus. Zootaxa, 1653, 57-68.

Pearson, T.H. (1970) Litocorsa stremma a new genus and species of pilargid (Polychaeta: Annelida) from the west coast of Scotland, with notes on two other pilargid species. Journal of Natural History, 4, 69-77.

Pettibone, M.H. (1966) Revision of Pilargidae (Annelida: Polychaeta), including descriptions of new species, and redescription of the pelagic Podarmus ploa Chamberlin (Polynoidae). Proceedings of the United States National Museum, 118, 115-207.

Russell, B. \& Smit, N. (2007) Report of a marine biodiversity survey on inshore soft bottom benthos of the SE Van Diemen Gulf and NW Arnhem Land between the Goulburn Islands and Castlereagh Bay, Northern Territory. Report to the Marine \& Biodiversity Division, Department of the Environment, Water, Heritage and the Arts, and Parks Australia North, 292 pp.

Saint-Joseph, B.A de. (1899) Annélides polychètes de la rade de Brest et de Paimpol. Annales des Sciences naturelles, 8(10), 161-194.

Salazar-Vallejo, S,I. (1987) Pilargidae (Annelida: Polychaeta) de Mexico: lista de especies, nueva especie y biografia. Cahiers de Biologie Marine, 27, 193-209.

Salazar-Vallejo, S.I. (2003) Revision of Synelmis Chamberlin, 1919 (Annelida, Polychaeta, Pilargidae). Zoosystema, 25(1), 17-42.

Salazar-Vallejo, S.I. \& Harris, L.H. (2006) Revision of Pilargis de Saint-Joseph, 1899 (Annelida, Polychaeta, Pilargidae). Journal of Natural History, 40(3-4), 119-159.

Salazar-Vallejo, S.I. and Orensanz, J.M. (1991) Pilárgidos (Annelida: Polychaeta) de Uruguay y Argentina. Cahiers de Biologie Marine, 32, 267-279.

Sun, D. \& Chen, B. (1990) A new species of Synelmis from offshore waters of China. Studia Marina Sinica, 31, 129-132.

Torgersen, T., Luly, J., de Deckker, P., Jones, M.R., Searle, D.E., Chivas, A.R. \& Ullman, W.J. (1988) Late Quaternary environments of the Carpentaria Basin, Australia. Palaeogeography, Palaeoclimatology, Palaeoecology, 67, 245-261.

Treadwell, A.L. (1941) Polychaetous annelids from the New England region, Porto Rico and Brazil. American Museum Novitates, 1138, 1-4.

Wilson, G.D.F. (2006) Arafura Sea Biological Survey: draft report on benthic fauna collected during RV Southern Surveyor voyage 05-2005 (30 April - 28 May 2005). Taxonomic results. Report prepared for the Department of the Environment and Heritage, Australia (Marine Division) by the Australian Museum.

Wolf, P.S. (1986) Three new species of Pilargidae (Annelida: Polychaeta) from the east coast of Florida, Puerto Rico and the Gulf of Mexico. Proceedings of the Biological Society of Washington, 99(3), 464-471.

Yokoyama, Y., Purcell, A., Lambeck, K. \& Johnston, P. (2001) Shore-line reconstruction around Australia during the last glacial maximum and late glacial stage. Quaternary International, 83-85, 9-18. 